\begin{tabular}{|l|l|l||}
\hline \multicolumn{2}{|c|}{ PublisherInfo } \\
\hline \hline PublisherName & $:$ & BioMed Central \\
\hline \hline PublisherLocation & $:$ & London \\
\hline \hline PublisherImprintName & $:$ & BioMed Central \\
\hline \hline
\end{tabular}

\title{
Seronegative arthritis discussion group
}

\begin{tabular}{|l|l|l||}
\hline \multicolumn{2}{|c|}{ ArticleInfo } \\
\hline \hline ArticleID & $:$ & 32 \\
\hline \hline ArticleDOI & $:$ & 10.1186 /ar-2000-2-webreport0001 \\
\hline \hline ArticleCitationID & $:$ & 0001 \\
\hline \hline ArticleSequenceNumber & $:$ & 28 \\
\hline \hline ArticleCategory & $:$ & Web Report \\
\hline \hline ArticleFirstPage & $:$ & 1 \\
\hline \hline ArticleLastPage & $:$ & 2 \\
\hline \hline & & RegistrationDate : 2000-11-9 \\
\hline ArticleHistory & $:$ & OnlineDate \\
\hline \hline ArticleCopyright & $:$ & Current Science Ltd2000-11-9 \\
\hline \hline ArticleGrants & $:$ & \\
\hline \hline ArticleContext & $:$ & 130752211 \\
\hline \hline
\end{tabular}




\section{Overview}

A remarkable presence in the field of seronegative arthritis is found in the web pages of this UKbased initiative. Using the cyberspace jargon, this site allows its members to 'chat'. Joining a discussion group specific to your interests, you can share your professional views with colleagues or patients. This type of service allows you to assist with and participate in the ongoing discussions by means of targeting either the general group or its specific members by email correspondence. Ultimately, this type of initiative could result in an emulation of referral services by providing an almost real-time worldwide referring forum.

\section{Last update}

Varies according to when messages are sent to the site. The most busy month had 11 messages posted to the website.

\section{References}

1. Mailbase: Seronegative arthritis. [http://www.mailbase.ac.uk/lists/seronegative-arthritis/] 